\title{
Post-transplant Shoot Growth of Trees From Five Different Production Methods is Affected by Site and Species
}

\author{
Anna Levinsson
}

\begin{abstract}
After transplanting, many trees enter a period of reduced growth that may limit their environmental and aesthetic benefits for several years. A number of nursery production methods have been developed in attempt to reduce root disturbance, which is often associated with the reduced growth. The main objective of this study was to investigate how five nursery production methods affect root systems and post-transplant shoot growth. Other objectives were the study of the effect of root structure (i.e., fibrous verses coarse) on trees' response to different production methods and the effect of the conditions at the transplanting site. Sweet cherry (Prunus avium L.) and red oak (Quercus rubra L.) with a stem circumference of 16-18 cm were produced as bare-rooted-, balled-and-burlapped-, root-pruned-, air-potted-, or fabric-container-grown trees, transplanted at two sites and studied for five seasons. Visual analysis showed that the production methods had clear effect on the root balls at transplanting. However, the differences were not clearly related to shoot growth. All transplanted red oaks, regardless of production method, showed significantly reduced shoot growth compared to pre-transplant growth. Balled and burlapped, root-pruned, and fabric-container-grown sweet cherry trees exhibited restored pre-transplant shoot growth three years after transplanting at the more favorable site. The results suggest that the fibrous-rooted sweet cherry was more responsive to production methods designed to reduce transplanting stress than the coarse-rooted red oak, and that site affected the time required for normal shoot growth to be regained. The results do not indicate that different sites require differently produced trees.

Key Words. Nursery Production; Prunus avium; Quercus rubra; Red Oak; Root Growth; Root Structure; Shoot Growth; Sweden; Sweet Cherry; Transplanting Stress; Urban Trees.
\end{abstract}

The presence of trees in urban areas has been reported to have several ecological, environmental, social, and human health- and wellbeing-related benefits (Beckett et al. 2000; Akbari 2002; Tyrvainen et al. 2007; Baris et al. 2009; Saebo et al. 2012). But for an urban tree to fulfill these values as an aesthetic and environmental resource, it needs to start putting on significant growth after transplanting (Day and Harris 2007). Benefits such as shading, particulate filtration, and $\mathrm{CO}_{2}$ sequestration increase as a tree's canopy grows (Fowler et al. 1989). However, trees often exhibit several years of low shoot growth after transplanting, something that has been attributed to disturbance of the root systems (Watson 1985; Harris et al. 2008; Struve 2009). For trees in traditional nursery production systems, such as field-grown bare-rooted (BR) or balled and burlapped $(\mathrm{B} \& \mathrm{~B})$ trees, much of the fine roots are lost during harvesting (Watson and Sydnor 1987). In attempts to reduce root disturbance and thus shorten the period of reduced growth, the tree nursery industry has developed several production methods with the aim of producing landscape-sized trees with large amounts of fine roots that are not lost during harvest (Appleton 1995). Different types of aboveground systems, such as air-pot systems (AP) or fabric-container (FC) in-ground systems, are examples of modern production systems where the trees are delivered with all the roots from the last years' nursery cultivation left in the root balls. Practices in the nurseries of the more recently developed production systems may somewhat differ between countries. In Sweden, for example, it is common practice to install field-grown trees in these sys- tems one or two years prior to transplanting. The purpose of this is to increase the amount fine roots just before transplanting and another intention is to let the trees experience their initial transplanting stress in the more controlled environment, provided by the nurseries. Therefore, these production methods are referred to as "pre-establishing systems" by the Swedish Nursery Association (GRO). Several advantages have been associated with the new production methods, such as higher flexibility in transplanting period and easier handling due to lighter growth media (Ferrini et al. 2000). Another more recent production method is in-ground root pruning, where the trees are root pruned (RP) for fine-root stimulation one year before harvest and left in the field. For the nursery industry, the introduction of new production methods involves high investment costs, but they have been shown to lead to higher production per unit land area and to be less labor-intense than the traditional in-field production (Adrian et al. 1998). The price to the consumer is, however, higher than that for a traditionally produced tree. It is therefore important to study whether modern production methods provide the expected benefits in terms of improved post-transplant shoot growth.

Shoot growth is dependent on several, often interacting, factors, such as environment, species, and ontogeny (Niklas 2004; Niinemets 2010). Water availability has been suggested to be the primary shoot growth limiting resource for young trees (Liu et al. 2012), and studies on different irrigation regimes and fertilization effects on tree growth after transplanting have supported this (Gilman 2004; Day and Harris 2007). The harvesting 
of field-grown trees in nurseries and the ensuing transplanting inevitably affect the root systems, disrupt the root:shoot balance, and impair the absorptive capacity of the tree. This means that not only water availability at the transplanting site, but also the tree's ability to take up water is a crucial factor for shoot growth after transplant (i.e., there must be a sufficient amount of vital roots for sustained water uptake and root regeneration). Field-grown trees have been shown to lose $32 \%$ of their total dry root weight at harvest, while the loss of fine-root length is as high as $88 \%$ (Gilman and Beeson 1996a). Regeneration of fine roots after transplanting is therefore crucial for the tree's ability to take up water and thus retain vigorous growth. Container-grown seedlings of red oak (Quercus rubra) have shown higher new root initiation on lateral roots than bare-rooted red oaks in a forestry study (Johnson et al. 1984) indicating that production systems may modify the root regeneration capacity.

Studies of the effect of production method on shoot growth have shown differing results. In a comparison between field-grown B\&B and BR Celtis occidentalis (L.), Ostrya virginiana (Mill.), and Quercus bicolor (Willd.), only B\&B Q. bicolor showed higher shoot growth than BR cultivated trees two years after planting (Buckstrup and Bassuk 2000). When field-grown B\&B were compared with plastic-container- and FC-grown plants, the production method was found to have no influence on growth rates 18 months after transplanting for either of the species Quercus laurifolia (Michx.) and Ilex $\times$ attenuata 'East Palatka' (Gilman and Beeson 1996b). No differences were found between production methods in a study of post-transplant growth of Acer rubrum (L.) produced in seven different container types (Marshall and Gilman 1998).

The extent to which a tree is influenced by production method after transplanting has also been shown to depend on the water availability (Gilman and Beeson 1996b). Under limited irrigation conditions, RP Quercus virginiana (Mill.) trees showed better survival and post-transplant growth than trees cultivated in various containers, while under well-irrigated conditions no differences were seen (Gilman 2001).

Previous studies have led scientists to formulate the hypothesis that the response of trees to production method is dependent on species and the conditions at the transplanting site (Struve 1993; Gilman 2001; Ferrini and Baietto 2006; Ferrini and Nicese 2006). It has also been hypothesized that root structure affects the response of the tree to the production method (Schuch et al. 2000). In general, trees with a coarse root system are considered more difficult to transplant than species with fibrous root systems because of their lower root regeneration potential (Struve 2009). A previous study on two species with different types of root structure indicated that fibrousrooted plants are more adaptable to growth in various types of container than coarse-rooted species (Schuch et al. 2000).

In this study, two tree species common in urban areas in northern Europe were compared: the fibrous-rooted sweet cherry (Prunus avium) and the coarse-rooted red oak. The objectives of the study were: 1 ) to determine the effect of production method on shoot growth in sweet cherry trees and red oak trees during one year in the nurseries and for four consecutive years after transplanting, 2) to compare how sweet cherry and red oak produced in different production methods responded to transplanting at an urban site and a controlled landscape site, 3) to study the influence of different production methods on root growth in the nursery for the two species with different root structures and to analyze if such differences might correspond to post-transplant shoot growth, 4) to evaluate the effect of the production method on the accumulated shoot growth for the two species during the period of the experiment, and 5) to study the time required for sweet cherry and red oak trees produced in different production systems to restore nursery shoot growth rates.

\section{MATERIALS AND METHODS}

\section{Plant Material and Experimental Conditions}

Sixty specimens of each species were included in the study. The trees of both species had a stem circumference of 14-17 cm, 1 meter above the root collar when the study started. Sweet cherry is a fibrous-rooted species with a determinate shoot growth pattern under natural Swedish growth conditions. All sweet cherry trees had the same provenance and had reached adult phase before the experiment started. Red oak is a coarse-rooted species with a semi-determinate shoot growth habit (Hanson et al. 1986; Struve 2009). Red oaks can have one or more shoot flushes per season, depending on how favorable the conditions are. None of the red oak trees had reached adult phase or set any fruit before transplanting. During the study, a few oak trees sporadically produced acorns. Most of the trees, however, stayed in the juvenile phase throughout the study. There was no detectable connection between fruit setting and production method, and it had no detectable effect on shoot growth. No red oak trees were therefore excluded due to fruit setting.

The study was carried out over five growing seasons, from 2007 to 2011. The trees were selected at two Swedish nurseries before the growing season of 2007. All plants within each species were produced at the same nursery (location of sweet cherry nursery: $56^{\circ} 13^{\prime} 40^{\prime \prime} \mathrm{N} 12^{\circ} 40^{\prime} 19^{\prime \prime} \mathrm{E}$, location of red oak nursery: $\left.58^{\circ} 39^{\prime} 21^{\prime \prime} \mathrm{N} \mathrm{16} 6^{\circ} 0^{\prime} 58^{\prime \prime} \mathrm{E}\right)$. All trees had been field grown until the selection in 2007. The selection was based on stem circumference and visual appearance, aiming at as high uniformity in visual appearance as possible. The size of stem circumference was determined based on the goal to deliver trees of the size of $16-18 \mathrm{~cm}$ the following spring. Within each species, the trees were then randomly categorized into five groups of twelve, each group submitted to a different production method: BR, B\&B, RP, AP, and $\mathrm{FC}$, and were cultivated for one more season in the nurseries.

The AP and the FC trees were moved to one of two other nurseries (depending on treatment) before the growth period of 2007. Each nursery specialized in the relevant production system. All four nurseries in the study are located in southern Sweden and have similar climatic prerequisites. All trees were then treated according to Swedish standard procedures for each production method (LRF 2012). BR and B\&B trees were left undisturbed in the fields. RP trees were root pruned before the growth season started and left in-ground, together with the $B R$ and $B \& B$ trees. The AP trees were transported as B\&B trees and were installed in air-pots (Superoots ${ }^{\circledR}$, The Caledonian Tree Company, Edinburgh, UK) filled with a peat-sand mixture and placed on a polypropylene ground cloth. The FC trees were transported to the new nursery as BR trees. They were root-pruned and installed in a peatfilled fabric container (Smart Pot ${ }^{\circledR}$, High Caliper, Oklahoma, U.S.) and placed in-field. All trees were drip-irrigated and AP trees also had crown-irrigation installed. The trees were 
given different amounts of fertilizers, depending on standard procedures for the production method. BR, B\&B, and RP trees were equally treated with one fertilization of NPK (11-5-18), distributed as $60 \mathrm{~kg} / 10000 \mathrm{~m}^{2}$, in the spring of 2007. The AP trees were fertilized one month after installation in the production system with approximately 11 NPK (21-3-10) for each tree. At installation of the FC trees, 220 g Osmocote ${ }^{\circledR}$ Pro (16-11-10), released over 8-9 months was included in each bag. Before the growing season started in the spring of 2008, 10 trees from each group were transplanted at the sites. The remaining two trees in each group were delivered to the experimental fields in Alnarp, Sweden, but not transplanted, and later used for root analysis.

Four trees from each group were planted in an urban


$\left.13^{\circ} 0{ }^{\prime} 9^{\prime \prime} \mathrm{E}\right)$, and the other six in the experimental fields at the Swedish University of Agricultural Sciences, Alnarp $\left(55^{\circ} 39^{\prime} 30^{\prime} \mathrm{N}, 13^{\circ} 05^{\prime} 0^{\prime \prime} \mathrm{E}\right)$. The trees were organized in a completely randomized block design for each site. The two sites are approximately $10 \mathrm{~km}$ away from each other. Both sites have a mean annual rainfall of approximately $600 \mathrm{~mm}$ and the difference in monthly mean temperature is $0.1^{\circ} \mathrm{C}$, with Malmö being the slightly warmer site. The trees planted in the city of Malmö were replacing old Ulmus trees, and were planted along two similar, parallel streets in a high-rise area, one species per street. The trees were planted in the positions that the Ulmus trees had previously grown until two years prior to replacement. Each pit was placed in a $3 \mathrm{~m}$ wide grass-covered area, irregularly interrupted by transverse pedestrian paths or minor roads to parking areas. The sidewalks of each street adjoined the planting areas on one side, and the driving lanes on the other. The streets ran from north to south, and were partially shaded by buildings. An area around each tree, one meter in diameter, was kept grass-free by a layer of gravel. The trees were managed by the municipality and irrigated approximately every second week during the first two growing seasons.

The planting site in Alnarp was an open field and all trees were sun-exposed during the whole day. The trees were placed at a distance of $4.5 \mathrm{~m}$ in rows and $4.5 \mathrm{~m}$ apart. The soil was covered with a single layer of polypropylene ground cloth $\left(\right.$ Mypex $\left.^{\circledR}\right)$ to inhibit weed growth. A drip-irrigation system was installed, and the plant water availability was regularly controlled using a $\mathrm{HH} 2$ moisture meter (Delta $\mathrm{T}$ Devices, Cambridge, UK) to avoid drought stress during the first two seasons. The irrigation frequency and amount was continuously modified so that the trees would have a sufficient water supply at all times. The trees were not fertilized at either of the two sites and no pruning was carried out.

\section{Measurements}

Shoot growth measurements were performed once every year between 2007 and 2011. The measurements were made after shoot growth cessation in each season. Two terminal shoots, and the lateral shoot next to the terminal, were measured in the middle part of the crown in the north, the south, the east, and the west (i.e., a total of 8 terminal and 8 lateral shoots in each tree). Any second flushes in the red oaks were noted, and the two parts were measured separately. The total shoot length of the growing season was used in the analysis.
$\mathrm{BR}$ and $\mathrm{B} \& \mathrm{~B}$ trees were not subjected to any kind of treatment during the nursery year (2007), and their shoot growth, during that year, can therefore be considered normal for the species(Struveetal.2000; Lietal.2010). Theirnursery shootgrowth was thus used as a reference for comparisons of the post-transplant shoot growth for all treatments during the consecutive years.

The root systems of the two randomly chosen trees in each group that were not transplanted were washed clean from soil and peat. Visual evaluations of root system density, amount of fine roots, and root depth and dispersal were recorded and the roots photographed. All roots less than $2 \mathrm{~cm}$ in diameter were then collected from the root ball and their root length was analyzed using a winRHIZO scanner (Régent Instruments, Canada). The roots were separated into fractions of $0-0.1 \mathrm{~mm}, 0.1-0.2$ $\mathrm{mm}, 0.2-0.4 \mathrm{~mm}, 0.4-0.6 \mathrm{~mm}, 0.6-0.8 \mathrm{~mm}, 0.8-1.0 \mathrm{~mm}, 1-2$ $\mathrm{mm}, 2-3 \mathrm{~mm}, 3-4 \mathrm{~mm}, 4-5 \mathrm{~mm}, 5-10 \mathrm{~mm}$, and $10-20 \mathrm{~mm}$.

\section{Data Analysis}

The trees were randomly distributed within each block. The blocks were species-specific and contained all production methods, resulting in a total of five trees per block. Annual shoot growth data were analyzed separately for the two species in a block design in SAS, using a model with block(site), site, production method, and the interaction site*production in the model. Accumulated shoot growth was calculated by summing the mean annual shoot growth for each tree and were then analyzed statistically with a General Linear Model, with production method and blocks as factors. To make a test to see if the trees had reached back to the shoot growth level of the undisturbed trees in the nurseries, a block design in PROC MIXED in SAS was used with repeated measurement for the trees where the unstructured covariance matrix was used because it turned out that this one had the smallest AIC. The contrast comparing the production method and year versus the mean of the undisturbed trees showed if the trees had recovered. The analyses were conducted using Minitab 15 Statistical Software (2007) for Windows (Minitab, Inc., State College, Pennsylvania, U.S.) and SAS (2008) (SAS version 9.2., SAS Institute Inc., Cary, North Carolina, U.S.) with a $5 \%$ significance level.

\section{RESULTS}

Tree survival was close to complete for all production methods and species during the study. One sweet cherry FC tree died in the nursery and one of the BR red oaks transplanted in Malmö died during the first winter after transplanting. One RP sweet cherry tree was excluded from the analysis because it was suspected that the roots had not been pruned. All $\mathrm{B} \& \mathrm{~B}$ trees and $\mathrm{AP}$ trees survived throughout the experiment.

\section{Comparison of the Two Sites}

As can be seen in Figure 1, site had a clear effect on shoot growth for both species during the two last years of the study (2010,2011), with significantly lower shoot growth in Malmö than at Alnarp (sweet cherry $P=0.0004$ and 0.0005 ; and red oak $P=0.0026$, and 0.0013 respectively). Sweet cherry shoot growth, however, was higher at the Malmö site $2009(P=0.0049)$, but for red oak, the shoot growth was higher at Alnarp also that year $(P=0.01)$. No differences between the sites were seen during the first post- 
transplant year, for either of the species. There was no interaction between production methods and sites during any of the posttransplant years for either of the species, showing that the site did not affect the production methods annual shoot growth capacity.



Figure 1. Annual shoot growth (mean $\pm \mathrm{SE}$ ) of sweet cherry and red oak during the nursery year of 2007 and during the four consecutive post-transplant years, produced as: • - BR (bare-rooted), $\Delta-$ B\&B (balled and burlapped), $\square-$ RP (root pruned), + - AP (air-potted), $\triangle-F C$ (fabric container) trees. The data points of BR and B\&B in 2007 show the shoot growth from undisturbed trees in the fields, while the other data points in 2007 represents trees subjected to root pruning or transplanting treatments. Each data point in Malmö is the mean of four trees' shoot growth and each data point in Alnarp is the mean of six trees' shoot growth. The mean value of each tree was calculated from 16 shoots.

\section{Annual Sweet Cherry Shoot Growth}

During the pre-transplant nursery year, 2007, the undisturbed $\mathrm{B} \& \mathrm{~B}$ and $\mathrm{BR}$ sweet cherry trees showed significantly higher shoot growth than the RP and FC trees $(P<0.0001)$. The AP trees showed shoot growth similar to that of the undisturbed sweet cherry trees, despite being lifted and installed in a new production system (Table 1).

As Table 1 also shows, there were significant differences between the production methods during the two first post-transplant years. However, the sweet cherry trees produced with all methods had very low shoot growth compared to the shoot growth of 2007's undisturbed sweet cherry trees and no production method had regained nursery shoot growth rates during these years (Figure 1).

After the shoot growth season of 2010, both sites showed higher shoot growth rates compared to the post-transplant shoot growth from the previous years. FC trees had significantly higher shoot growth than AP and BR, with both sites included in the analysis $(P=0.001)$. None of the Malmö planted sweet cherry trees had returned to nursery shoot growth rates, while all Alnarp sweet cherry trees except the BR and AP trees had restored pre-transplant shoot growth (Figure 1).

In 2011, the FC trees still had higher shoot growth than the $\mathrm{BR}$, but were no longer separated from the AP trees. In Malmö, shoot growth with all production methods was still significantly lower than that of the undisturbed trees growth in 2007. The sweet cherry trees at Alnarp 2011 again showed significantly lower shoot growth than the undisturbed 2007's trees (Figure 1). Shoot growth was, however, higher than in 2008 and 2009 for all production methods at both sites (Figure 1).

\section{Annual Red Oak Shoot Growth}

The undisturbed B\&B and BR red oaks showed significantly higher shoot growth than trees produced with all the other methods in the nurseries in $2007(P<0.0001)$. RP red oaks showed significantly lower shoot growth than $\mathrm{B} \& \mathrm{~B}$ and $\mathrm{BR}$ trees, but exhibited significantly better growth than AP and FC trees (Table 1).

The shoot growth for the red oaks grown with all methods was very low after shoot growth cessation in 2008 compared to the shoot growth of the undisturbed field-grown red oaks in 2007 (Figure 1). Significant differences were however seen between the production methods $(P<0.0001)$ with $\mathrm{B} \& \mathrm{~B}$ trees showing higher shoot growth than BR, FC, and RP trees.

During the last three years, shoot growth was only a small fraction of that of the undisturbed red oaks in 2007 (Figure 1). There were however annual differences between the production methods in both 2009 and 2010, with AP trees showing a higher shoot growth than RP trees in each. The red oaks at Alnarp showed slightly greater shoot growth in 2011 than 2010, but growth was still far lower than that of the undisturbed field-grown trees in 2007 (Figure 1).

\section{Accumulated Shoot Growth of Both Species}

In order to estimate the impact of the production method on the size of the crown four years after transplanting and on the total shoot growth during the period of the study, the accumulated shoot growth was calculated with and without the nursery year (Table 2). The shoot growth of sweet cherry trees in Malmö varied with the production method when the nursery year was included in the analysis $(P=0.029)$. AP and $\mathrm{B} \& \mathrm{~B}$ sweet cherry trees showed significantly higher shoot growth than RP trees $(P=0.025)$. This difference was not significant when the data from the nursery growth rates of 2007 were excluded, showing that post-transplant growth rates did not differ between the production methods. This shows that the shoot growth in the nursery still had a significant impact on the accumulated shoot growth determined four years after the transplanting of this species at the urban planting site.

For the red oaks, differences in accumulated shoot growth were seen among the trees produced with the different methods at both sites when all years were included in the analysis. Red oaks that were not disturbed until transplanting (B\&B and BR) still showed significantly higher accumulated growth four years after transplanting than the red oaks that had been produced using other methods in 2007 ( $P<0.0001$ at both sites).

Excluding the year in the nursery also showed differences in accumulated shoot growth between the production methods (Table 2). RP red oaks showed the lowest accumulated growth at both sites. However, the method producing red oaks 
Table 1. Mean annual shoot growth of the five production methods for sweet cherry trees and red oak trees, including both Malmö and Alnarp sites.

\begin{tabular}{|c|c|c|c|c|c|c|c|c|c|c|}
\hline & Sweet cherry & & & & & Red oak & & & & \\
\hline Year & 2007 & 2008 & 2009 & 2010 & 2011 & 2007 & 2008 & 2009 & 2010 & 2011 \\
\hline Stage in trial & Pre-transp. & Post-transp1 & Post-transp2 & Post-transp3 & Post-transp4 & Pre-transp. & Post-transp1 & Post-transp2 & Post-transp3 & Post-transp4 \\
\hline$\overline{\mathrm{BR}}$ & $41.6 \mathrm{a}$ & $3.6 \mathrm{c}$ & $9.6 \mathrm{a}$ & $16.0 \mathrm{c}$ & $18.9 \mathrm{~b}$ & $50.0 \mathrm{a}$ & $8.3 b c$ & $6.6 \mathrm{ab}$ & $5.96 \mathrm{ab}$ & $10.8 \mathrm{a}$ \\
\hline $\mathrm{RP}$ & $9.9 \mathrm{~b}$ & $6.0 \mathrm{bc}$ & $4.8 \mathrm{ab}$ & $31.6 \mathrm{ab}$ & $24.0 \mathrm{ab}$ & $34.3 b$ & $4.2 \mathrm{c}$ & $3.7 \mathrm{~b}$ & $3.7 b$ & $8.7 \mathrm{a}$ \\
\hline $\mathrm{AP}$ & $42.2 \mathrm{a}$ & $13.6 \mathrm{a}$ & $5.0 \mathrm{ab}$ & $20.4 \mathrm{bc}$ & $19.3 \mathrm{ab}$ & $18.9 \mathrm{c}$ & $11.2 \mathrm{ab}$ & $10.2 \mathrm{a}$ & $6.6 \mathrm{a}$ & $10.4 \mathrm{a}$ \\
\hline $\mathrm{FC}$ & $10.8 b$ & $9.6 a b$ & $4.1 \mathrm{~b}$ & $35.1 \mathrm{a}$ & $27.5 \mathrm{a}$ & $15.8 \mathrm{c}$ & $8.2 \mathrm{bc}$ & $4.5 \mathrm{~b}$ & $5.2 \mathrm{ab}$ & $10.4 \mathrm{a}$ \\
\hline$P$-values & $<0.0001$ & 0.0002 & 0.0253 & 0.0010 & 0.0200 & $<0.0001$ & $<0.0001$ & 0.0177 & 0.0373 & 0.8767 \\
\hline
\end{tabular}

Note: BR - bare-rooted, B\&B - balled and burlapped, RP - root-pruned, AP - air-potted, FC - fabric container. Means within a column are based on 10 trees' shoot growth. Different letter indicates significant differences at 0.05 level using Tukey's test.

Table 2. Mean accumulated shoot growth of sweet cherry and red oak, including and excluding the nursery year (2008), in Malmö and Alnarp sites.

\begin{tabular}{|c|c|c|c|c|c|c|c|c|}
\hline \multirow{3}{*}{ Treatment } & \multicolumn{4}{|l|}{ Sweet cherry } & \multicolumn{4}{|l|}{ Red oak } \\
\hline & 2007-2011 & & 2008-2011 & & 2007-2011 & & 2008-2011 & \\
\hline & Malmö & Alnarp & Malmö & Alnarp & Malmö & Alnarp & Malmö & Alnarp \\
\hline $\mathrm{BR}$ & $72.9 \pm 13.1 \mathrm{ab}$ & $101.8 \pm 9.3$ & $33.9 \pm 12.7$ & $62.4 \pm 10.1 \mathrm{a}$ & $70.0 \pm 10.3 \mathrm{a}$ & $89.5 \pm 12.2 \mathrm{ab}$ & $22.7 \pm 2.8 \mathrm{ab}$ & $36.3 \pm 14.6 \mathrm{ab}$ \\
\hline $\mathrm{RP}$ & $50.3 \pm 23.9 b$ & $106.6 \pm 10.4$ & $42.9 \pm 22.1$ & $89.5 \pm 7.3 \mathrm{a}$ & $47.8 \pm 5.9 b$ & $59.3 \pm 12.8 c$ & $12.4 \pm 2.6 b$ & $26.3 \pm 11.9 b$ \\
\hline $\mathrm{AP}$ & $84.8 \pm 14.2 \mathrm{a}$ & $116.3 \pm 23.3$ & $41.8 \pm 11$ & $75.0 \pm 21.5 a$ & $44.8 \pm 12.5 b$ & $68.4 \pm 19.5 b c$ & $25.1 \pm 8.9 \mathrm{ab}$ & $50.3 \pm 13.9 \mathrm{a}$ \\
\hline $\mathrm{FC}$ & $71.7 \pm 14.1 \mathrm{ab}$ & $102.6 \pm 23.6$ & $59.8 \pm 18.6$ & $92.9 \pm 24 \mathrm{a}$ & $33.3 \pm 6.9 b$ & $52.5 \pm 11.8 \mathrm{c}$ & $20.8 \pm 7 \mathrm{ab}$ & $33.5 \pm 6.6 \mathrm{ab}$ \\
\hline$P$-values & 0.029 & 0.640 & 0.193 & 0.035 & 0.000 & 0.000 & 0.025 & 0.003 \\
\hline
\end{tabular}

Note: BR - bare-rooted, B\&B - balled and burlapped, RP - root-pruned, AP - air-potted, FC - fabric container. Means within a column followed by a different letter are significantly differed from each other at 0.05 level using Tukey's test.

with the higher accumulated post-transplant shoot growth differed between the two sites. AP trees showed the highest accumulated shoot growth at Alnarp and B\&B trees in Malmö.

\section{Root Systems}

The production methods appeared to have considerable effects on the visual appearance of the root systems (Figure 2). All roots investigated had relatively shallow root systems with roots in all directions. The root systems within each species appeared to have the same amount of first-and second-order lateral roots. For FC grown trees, these roots were more shortened due to the root pruning that took place before the trees were installed in the fabric containers. Both species grown with the AP and FC methods responded vigorously, producing root systems that gave an impression of a high density of small-diameter roots. The FC root systems appeared very compact, and the small-diameter roots were evenly spread throughout the fabric container. The majority of the small-diameter roots of the AP root systems were found in the outer part of the root ball, where the peat had been located. The root systems of B\&B and BR trees had small amounts of smalldiameter roots. $\mathrm{B} \& \mathrm{~B}$ root systems were more compact than $\mathrm{BR}$ root systems. The two species reacted differently to root pruning, which seemed to stimulate the growth of small-diameter roots in sweet cherry trees, whereas the effect was much less in red oak. The root system of RP red oak trees was not visually different from that of the B\&B trees, but a difference was seen between sweet cherry trees produced with these two methods. RP sweet cherry trees appeared to have the densest root system of all the sweet cherry trees, with small-diameter roots throughout the root ball.

WinRHIZO scanning (Figure 3) showed that sweet cherry trees had almost twice the number of small-diameter roots of red oak. The scannings also showed that there were great variations in total fine-root length between the production methods. For both species, the trees that were not exposed to any fine-root stimulating measures had the lowest amount of total fine-root length. There were however also differences between the fine-root stimulating production methods (i.e., the pre-establishing systems). RP sweet cherry trees had the highest total fine-root length and the AP sweet cherry trees had $83 \%$ of their total length of fine roots. FC sweet cherries had 37\%, compared to the RP trees. Red oak RP trees had only $29 \%$ of the amount that the AP red oak trees had and FC red oak trees had 59\% of the AP trees length. For both species, the fraction of $0.4-0.6 \mathrm{~mm}$ seemed to have the highest number of fine roots.

Since only two trees from each group were used for the root studies, the observations can only indicate tendencies and give background information.

\section{DISCUSSION}

Transplant stress has been defined as a temporary condition of distress during which the plant experiences impaired functions caused by the handling of the plant, from the lifting in the nursery to the planting into new, and often less favorable, growing conditions (Rietveld 1989). The definition also includes a period of recovery and adaption to the new environment. It is also stated that some degree of stress is inevitable, even under ideal planting conditions. The results from this study are well in line with the definition, since post-transplant shoot growth of all trees in this study was negatively affected by transplanting, irrespective of the production method, site, or species. The impaired functions manifested as very low shoot growth during the first two post-transplant years for trees of both species at both sites, compared to the pre-transplant growth of the undisturbed trees. Rietveld (1989) also states that the outcome of the stress depends on the interactions between the plant performance potential and the site conditions. In this study, the severity, in terms of reduced 




Figure 2. Examples of clear-cleaned root systems of sweet cherry trees and red oak trees produced as : BR (bare-rooted), B\&B (balled and burlapped), RP (root pruned), AP (air-potted), FC (fabric container) trees, after lifting from the nurseries, at the time of transplanting.

shoot growth, and the duration of the transplant stress differed between the production methods, the species, and the two sites. This has also been reported in several previous studies (Buckstrup and Bassuk 2000; Jacobs et al. 2009; Koeser et al. 2009).

The AP and FC production methods applied in this study included exposing the trees to transplanting stress already in the

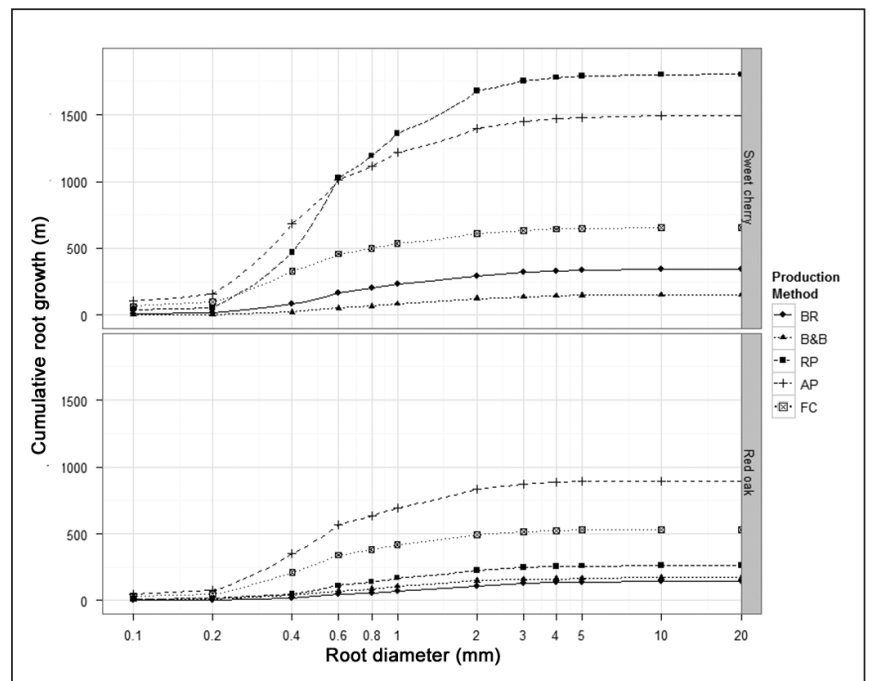

Figure 3. Mean cumulative root growth for: • - BR (bare-rooted), $\Delta-B \& B$ (balled and burlapped), - - RP (root-pruned), + - AP (airpotted), $\square-F C$ (fabric container) trees, based on measurements from two sweet cherry root systems (top) root systems and two red oak root systems (bottom).

nurseries, when the trees were lifted from the fields and installed in the new production systems, in the so-called pre-establishing systems. Most of the trees that were exposed to any kind of root disturbance in the nurseries reacted with reduced shoot growth during that year. The sweet cherry AP trees were the exception, however, showing shoot growth as high as the undisturbed sweet cherry trees despite the inevitable disruption of the root systems when the trees were installed. The unexpectedly high shoot growth indicates that the growing conditions in the AP system were so favorable for the sweet cherry trees that transplanting stress was not detectable on shoot growth. The results from the posttransplant growth in this study did not give the indications that the trees treated in the "pre-establishing systems" had the clear advantages after transplant that is expected by the industry. The response to these production systems might have been different, however, if the trees had been cultivated for one more yearin these pre-establishing systems before transplanting. Clearly, it could be of interest in future studies to evaluate potential differences in transplanting stress between one and two years of pre-establishing cultivation.

Comparison of the influence of production method on annual shoot growth for each species at Malmö and Alnarp showed that the reactions to the production methods were the same at the two sites, despite the different growth conditions. The results indicate that the site may not be of fundamental importance to the response of a species to a given production method. The results suggest that the growing conditions were more favorable at Alnarp, since the trees of both species showed a higher shoot growth at that site, after the initial transplant shock. Regardless of the conditions at the site, the same production methods led to higher shoot growth at both planting sites within each species. However, the time required for the trees to regain pre-transplant growth rate differed between the sites. The red oak trees had still not regained their pre-transplant growth rate at either of the sites four years after transplanting, while the growth rate of the $\mathrm{B} \& \mathrm{~B}, \mathrm{RP}$, and FC sweet cherry trees had been restored at Alnarp after three years. These results indicate that both plant material and growing conditions 
influenced the duration of the transplanting stress, as has been stated in the definition of transplanting stress (Rietveld 1989). The reduced growth rates for sweet cherry trees, observed for most of the production methods at Alnarp in 2011, compared to 2010, may be the result of increased complexity of the crown associated with the vigorous lateral shoot growth in 2010 (Borchert 1976).

Previous studies have shown that water availability is the main limiting resource in vegetative growth, and that nutrient supply is less important during the establishment phase (Day and Harris 2007; Liu et al. 2012). The frequent irrigation at Alnarp could be one explanation of the more rapid recovery of shoot growth in sweet cherry trees at that site, but comparison of the two sites showed that the shoot growth was not higher at Alnarp during the first two post-transplant years, when the trees were irrigated. This indicates that the ability of the root system to take up water was limited during the first year, regardless of the water availability and the method used for cultivation. Even though the more frequent irrigation at Alnarp had no initial positive effect on shoot growth, it might have had a positive effect on root regeneration. Studies have shown that even minor soil moisture stress reduces root regeneration (Larson and Whitmore 1970), thereby prolonging the time for a transplanted tree to restore a balance between root and crown, roots to explore the new soil and to obtain the necessary contact with the growth medium. Soil moisture stress might have slowed the process of recovery from transplanting stress for the Malmö-situated trees to a greater extent than for the Alnarp-planted trees.

Shoot growth patterns differed between the species, with seemingly better acclimation of the fibrous-rooted sweet cherry. These results support a previous hypothesis on species-specific responses to nursery production methods (Struve 1993; Schuch et al. 2000; Ferrini and Baietto 2006). Differences in time for recovery of pretransplant growth rates between the species might also be a result of the species root:shoot ratio. Red oak is generally considered to be a species with a high root:shoot ratio, which could prolong the time required for the species to return to the pre-transplant root:shoot ratio to a greater extent than for a species with a lower ratio, and higher root regeneration potential, as sweet cherry.

The trees in this study were planted before budbreak in spring, and one of the advantages of modern production methods is the greater flexibility in transplanting period (Ferrini et al. 2000). The results of this study might have been different for red oak if the trees had been planted at another time of year, when planting of field-grown red oak trees is normally not recommended. Earlier studies on the effect of transplanting time for establishment, however, have not shown any clear results regarding which time of year is most beneficial for transplanting in general (Solfjeld and Hansen 2004; Richardson-Calfee et al. 2007).

It has been argued that for a tree to exhibit significant aboveground growth there must be a balance between the root and the crown (Borchert 1973; Brouwer 1983). The functional balance hypothesis describes the continuous modification of roots and shoots to obtain a ratio that is favorable in a certain development phase under a great variety of environmental conditions (Brouwer 1983). Although the observed differences between the root systems were large, the differences in shoot growth between the different production systems were not as pronounced. There was no clear relation between the amount of fine roots at delivery from the nurseries and post-transplant shoot growth in the trees in the current study. The AP and RP sweet cherry trees that were examined had the highest amount of small-diameter roots, but the possible advantage of this was only detectable in AP trees during the first post-transplant year. RP sweet cherry trees instead showed poor initial shoot growth. If the higher shoot growth shown by RP trees at both sites later in the experiment (three and four years after transplanting) was related to the high amount of fine roots at transplant, this positive effect was not evident in the AP trees, which initially had the same amount of fine roots. One explanation for this may be that the different production methods create roots of different quality, or with different regeneration capacity. A previous study on red oak has shown that container-grown seedlings produced more first-order lateral roots than bare-rooted red oak seedlings, suggesting that the root architecture developed in the container is more favorable for root regeneration (Wilson et al. 2007). No data on root regeneration after transplanting was collected in this study, but the differences in shoot growth between RP and AP sweet cherry trees in 2010 might be an indication that root pruning had a more positive effect on root regeneration, ensuring long-term survival.

Considerable visual differences were noted in the root systems of the trees in this study, and some of these different appearances may have been more favorable for root regeneration. The lack of a relationship between total fine-root length and shoot growth might also be due to the different medium surrounding the roots. It has previously been shown that there is a risk that containergrown trees will have very dry soil after transplanting, since the porous medium often used has a lower water-holding capacity than the surrounding soil (Nelms and Spomer 1983; Hanson et al. 2004). The water may be drawn out of the root ball, leading to a water deficit, despite irrigation and vigorous root systems (Harris 2007). Similar observations were made during this study. The root balls of the AP trees at Alnarp dried out faster than the other root balls with the nursery's natural soil (data not shown), something that was probably due to structural differences between the peat-filled root ball and the surrounding soil in the experimental field. This could explain why AP sweet cherry trees did not benefitmore from the larger rootball and higher amount of fine roots.

Sweet cherry and red oak reacted very differently to root pruning in the nursery: the WinRhizo-analysis and the visual observations showed that pruning seemed to stimulate root growth in sweet cherry but not in red oak.

No differences were noted between the production methods in the accumulated shoot growth of the sweet cherry trees at Alnarp when all the years were included, since the initially highperforming production methods were the lower-performing ones during the second half of the experiment. Shoot growth was thus evened out over the years, resulting in trees of equal size four years after transplanting, for all production methods. Assuming that growth continues at the current rate, the trees will remain equal in size. The production method would, in such a case, have little long-term effect on the size of the tree. The effect of the production methods in a longer perspective was not studied here and production method may affect long-term mechanical stability due to potential differences in root system regeneration and development. Such differences could affect survival and growth, and are complicating forecasts on future canopy sizes. To make longterm studies on production methods influence on shoot growth and canopy size would therefore be highly relevant. The accumulated shoot growth-results for the sweet cherry trees planted in Malmö differed from the Alnarp-results. The post-transplant 
differences between the production methods were smaller, and the growth was thus not evened out. The size advantage of the high-performing trees from the nurseries was still detectable four years later. Red oak showed similar results in Malmö, with the $\mathrm{B} \& \mathrm{~B}$ red oaks showing the highest accumulated shoot growth. Red oak did not seem to show a positive response to root pruning in the nursery at either of the sites. Excluding the nursery year, AP red oaks showed the highest accumulated shoot growth at Alnarp. If this trend were to continue, the AP red oaks at Alnarp could become larger than red oaks cultivated with other methods, although the annual differences were not statistically significant.

It cannot be excluded that the different nutritional standard practices in the nurseries and the different substrates in the rootballs for several of the production systems, also had some effect on post-transplant shoot growth on the trees in this study. A previous study has shown that shoot growth was strongly determined by the availability of a tree's internal $\mathrm{N}$ stores and that current $\mathrm{N}$ supply was less important (Dyckmans and Flessa 2001). This could mean that shoot growth during the first year after transplanting was effected by the amount of nitrogen provided in the nursery. There were however significant differences between the trees from the field-grown production systems of both species $(\mathrm{BR}, \mathrm{B} \& \mathrm{~B}$, and $\mathrm{RP})$ the first year after transplanting, even though they had the same nutritional prerequisites from the nurseries and the coarse roots that provide storage for $\mathrm{N}$ were equal in amount between these production methods, indicating that other factors had higher influence on shoot growth than nitrogen supply from the nursery.

This study provided no clear answer as to which production method is best for ensuring a significant shoot growth after transplant. Annual shoot growth measurements showed that there were differences in several of the years for both species, but shoot growth was significantly reduced after transplanting of trees cultivated with all the methods investigated, also the "preestablishing" systems. To study what effect a longer period of cultivation in these systems could have on post-transplant shoot growth would therefore be interesting. B\&B, RP and FC sweet cherry trees planted at Alnarp did, however, exhibit nursery shoot growth rates during the third season after transplanting, indicating an advantage of these production methods for sweet cherry. However, the accumulated shoot growth revealed that FC and RP trees would probably not be bigger than trees cultivated with other methods four years after transplanting, due to low shoot growth in the nursery with these two methods of production. The study raised interest in further investigations on production methods' long-term effect on shoot growth. Red oak did not exhibit nursery shoot growth rates for any of the production methods at either of the sites, showing that more time is required for studying shoot-growth recovery for red oak under these conditions. In this study, the conditions at the sites affected the time taken for the trees to regain their normal growth rates, but had no influence on which production method was more favorable for a particular site. There was also no clear correspondence between root system appearance at transplanting and post-transplant growth, indicating that more factors than amount of fine roots are of importance for a successful post-transplant shoot growth.
Acknowledgments. This work was supported by Swedish Farmers Foundation of Agricultural Research, SLF; the city of Malmö and the Federation of Swedish Farmers, the Nursery section, GRO. Jan-Eric Englund helped with statistical analyses and I thank him as well as Ann-Mari Fransson for valuable comments during the writing process.

\section{LITERATURE CITED}

Adrian, J.L., C.C. Montgomery, B.K. Behe, P.A. Duffy, and K.M. Tilt. 1998. Cost comparisons for infield, above ground container and Pot-in-Pot production systems. Journal of Environmental Horticulture 16:65-68.

Akbari, H. 2002. Shade trees reduce building energy use and $\mathrm{CO}_{2}$ emission from power plants. Environmental Pollution 116:119-126.

Appleton, B.L. 1995. Nursery production methods for improving tree roots - An update. Journal of Arboriculture 21:265-270.

Baris, M.E., S. Sahin, and M.E. Yazgan. 2009. The contribution of trees and green spaces to the urban climate: The case of Ankara. African Journal of Agricultural Research 4:791-800.

Beckett, K.P., P.H. Freer-Smith, and G. Taylor. 2000. The capture of particulate pollution by trees at five contrasting urban sites. Arboricultural Journal 24:209-230.

Borchert, R. 1973. Simulation of rhythmic tree growth under constant conditions. Physiologia Plantarum 29:173-180.

Borchert, R. 1976. Differences in shoot growth patterns between juvenile and adult trees and their interpretation based on systems analysis of trees. Acta Horticulturae (Wageningen) 56:123-130.

Brouwer, R. 1983. Functional equilibrium - Sense or nonsense. Netherlands. Journal of Agricultural Science 31:335-348.

Buckstrup, M.J., and N.L. Bassuk. 2000. Transplanting success of balled-and-burlapped versus bare-root trees in the urban landscape. Journal of Arboriculture 26:298-308.

Day, S.D., and J.R. Harris. 2007. Fertilization of red maple (Acer rubrum) and littleleaf linden (Tilia cordata) trees at recommended rates does not aid tree establishment. Arboriculture \& Urban Forestry $33: 113-121$.

Dyckmans, J., and H. Flessa. 2001. Influence of tree internal N status on uptake and translocation of $\mathrm{C}$ and $\mathrm{N}$ in beech: A dual C-13 and N-15 labeling approach. Tree Physiology 21:395-401.

Ferrini, F., and F.P. Nicese. 2006. Effect of container type nursery techniques on growth and chlorophyll content of Acer platanoides L. and Liquidambar styraciflua L. plants. Journal of Food Agriculture \& Environment 4:209-213.

Ferrini, F., and M. Baietto. 2006. Response to fertilization of different tree species in the urban environment. Arboriculture \& Urban Forestry 32:93-99.

Ferrini, F., F.P. Nicese, S. Mancuso, and A. Giuntoli. 2000. Effect of nursery production method and planting techniques on tree establishment in urban sites: Preliminary results. Journal of Arboriculture 26:281-284

Fowler, D., J.N. Cape, and M.H. Unsworth. 1989. Deposition of atmospheric pollutants on forests. Philosophical Transactions of the Royal Society of London Series B-Biological Sciences 324:247-265.

Gilman, E.F. 2001. Effect of nursery production method, irrigation, and inoculation with mycorrhizae-forming fungi on establishment of Quercus virginiana. Journal of Arboriculture 27:30-38. 
Gilman, E.F. 2004. Effects of amendments, soil additives, and irrigation on tree survival and growth. Journal of Arboriculture 30:301-310.

Gilman, E.F., and R.C. Beeson, Jr. 1996a. Nursery production method affects root growth. Journal of Environmental Horticulture 14:88-91.

Gilman, E.F., and R.C. Beeson, Jr. 1996b. Production method affects tree establishment in the landscape. Journal of Environmental Horticulture 14:81-87.

Hanson, A.M., J.R. Harris, R. Wright, A. Niemiera, and N. Persaud. 2004. Water content of a pine-bark growing substrate in a drying mineral soil. Hortscience 39:591-594.

Hanson, P.J., R.E. Dickson, J.G. Isebrands, T.R. Crow, and R.K. Dixon. 1986. A morphological index of Quercus seedling ontogeny for use in studies of physiology and growth. Tree Physiology 2:273-281.

Harris, J.R. 2007. Transplanting large trees. CAB Reviews: Perspectives in Agriculture, Veterinary Science, Nutrition and Natural Resources 2.7 pp.

Harris, J.R., S.D. Day, and B. Kane. 2008. Nitrogen fertilization during planting and establishment of the urban forest: A collection of five studies. Urban Forestry \& Urban Greening 7:195-206.

Jacobs, D.E., K.F. Salifu, and A.S. Davis. 2009. Drought susceptibility and recovery of transplanted Quercus rubra seedlings in relation to root system morphology. Annals of Forest Science 66.

Johnson, P.S., S.L. Novinger, and W.G. Mares. 1984. Root, shoot, and leaf-area growth potentials of northern red oak planting stock. Forest Science 30:1017-1026.

Koeser, A.K., J.R. Stewart, G.A. Bollero, D.G. Bullock, and D.K. Struve. 2009. Impacts of handling and transport on the growth and survival of balled and burlapped trees. Hortscience 44:53-58.

Larson, M.M., and F.W. Whitmore. 1970. Moisture stress affects root regeneration and early growth of red oak seedlings. Forest Science 16:495.

Li, B., Z. Xie, A. Zhang, W. Xu, C. Zhang, Q. Liu, C. Liu, and S. Wang. 2010. Tree growth characteristics and flower bud differentiation of sweet cherry (Prunus avium L.) under different climate conditions in China. Horticultural Science 37:6-13.

Liu, B.H., L. Cheng, M.J. Li, D. Liang, Y.J. Zou, and F.W. Ma. 2012. Interactive effects of water and nitrogen supply on growth, biomass partitioning, and water-use efficiency of young apple trees. African Journal of Agricultural Research 7:978-985.

LRF (Federation of Swedish Farmers). 2012. Kvalitetsregler för plantskoleväxter (Quality rules for nursery plants). Accessed 06/14/2013. $<$ www.lrf.se/PageFiles/98759/Kvalitetsregler\%20slutgiltig.pdf>

Marshall, M.D., and E.F. Gilman. 1998. Effects of nursery container type on root growth and landscape establishment of Acer rubrum L. Journal of Environmental Horticulture 16:55-59.

Nelms, L.R., and L.A. Spomer. 1983. Water-retention of container soils transplanted into ground beds. Hortscience 18:863-866.

Niinemets, U. 2010. Responses of forest trees to single and multiple environmental stresses from seedlings to mature plants: Past stress history, stress interactions, tolerance, and acclimation. Forest Ecology and Management 260:1623-1639.

Niklas, K.J. 2004. Plant allometry: Is there a grand unifying theory? Biological Reviews 79:871-889.

Richardson-Calfee, L.E., J.R. Harris, and J.K. Fanelli. 2007. Posttransplant root and shoot growth periodicity of sugar maple. Journal of the American Society for Horticultural Science 132:147-157.
Rietveld, W.J. 1989. Transplanting stress in bare root conifer seedlings: Its development and progression to establishment. Northern Journal of Applied Forestry 6:99-107.

Saebo, A., R. Popek, B. Nawrot, H.M. Hanslin, H. Gawronska, and S.W. Gawronski. 2012. Plant species differences in particulate matter accumulation on leaf surfaces. Science of the Total Environment 427:347-354.

Schuch, U.K., D.R. Pittenger, and P.A. Barker. 2000. Comparing effects of container treatments on nursery production and field establishment of trees with different root systems. Journal of Environmental Horticulture 18:83-88.

Solfjeld, I., and O.B. Hansen. 2004. Post-transplant growth of five deciduous Nordic tree species as affected by transplanting date and root pruning. Urban Forestry \& Urban Greening 2:129-137.

Struve, D.K. 1993. Effect of copper-treated containers on transplant survival and regrowth of four tree species. Journal of Environmental Horticulture 11:196-199.

Struve, D.K. 2009. Tree establishment: A review of some of the factors affecting transplant survival and establishment. Arboriculture \& Urban Forestry 35: unpaginated.

Struve, D.K., L. Burchfield, and C. Maupin. 2000. Survival and growth of transplanted large- and small-caliper red oaks. Journal of Arboriculture 26:162-169.

Tyrvainen, L., K. Makinen, and J. Schipperijn. 2007. Tools for mapping social values of urban woodlands and other green areas. Landscape and Urban Planning 79:5-19.

Watson, G. 1985. Tree size affects root regeneration and top growth after transplanting. Journal of Arboriculture 11:37-40.

Watson, G.W., and T.D. Sydnor. 1987. The effect of root pruning on the root system of nursery trees. Journal of Arboriculture 13:126-130.

Wilson, E.R., K.C. Vitols, and A. Park. 2007. Root characteristics and growth potential of container and bare-root seedlings of red oak (Quercus rubra L.) in Ontario, Canada. New Forests 34:163-176.

\section{Anna Levinsson}

Dept. of Landscape Architecture, Planning, and Management

Swedish University of Agricultural Sciences

Alnarp, Sweden

Anna.Levinsson@slu.se 
Zusammenfassung. Nach der Verpflanzung haben viele Bäume eine Periode mit vermindertem Wachstum, was ihr ästhetisches Erscheinungsbild und ihre ökologischen Leistungen für ein paar Jahre limitiert. Es wurden daher eine Reihe von Baumschulproduktionsmethoden entwickelt, um den Verpflanzungsschock für den Wurzelballen zu reduzieren. Das Hauptziel dieser Studie lag darin herauszufinden, wie fünf Produktionsmethoden das Wurzelsystem und den Schock nach der Verpflanzung beeinflussen. Andere Ziele waren einerseits eine Studie des Einflusses der Wurzelstruktur (z.B. fein versus grob) auf die Reaktion des Baumes bei unterschiedlichen Produktionsmethoden und welchen Einfluss die Standortbedingungen haben. Vogelkirschen (Prunus avium L.) und Roteichen (Quercus rubra L.) mit einem Stammumfang von 16-18 cm wurden als Wurzelware, Ballenware, mit Wurzelschnitt, in Luft-Topfung oder in textilen Pflanzcontainern gezogen, an zwei Standorte verpflanzt und über fünf Vegetationsperoiden untersucht. Eine visuelle Analyse zeigte, dass die Produktionsmethoden einen klaren Einfluß auf den Wurzelballen. Dennoch waren die Unterschiede nicht eindeutig mit dem Triebwachstum verbunden. Alle verpflanzten Eichen, unabhängig von der Produktionsmethode, zeigten deutlich reduzierte Triebe im Vergleich zum Wachstum vor der Verpflanzung. Die Vogelkirschen als Ballenware, mit Wurzelschnitt oder in textilen Pflanzcontainern gezogen zeigten erst drei Jahre nach der Verpflanzung an den besseren Standorten eine Erholung des Trieblängenwachstums. Die Ergebnisse dieser Studie verdeutlichen, dass Vogelkirschen mit einem feinen Wurzelsystem mehr Reaktion auf eine Produktionsmethode zur Reduzierung des Verpflanzungsschocks zeigten als Roteichen mit einem groben Wurzelsystem und dass der Standort die erforderliche Zeit zur Erholung des Wachstums beeinflusst. Die Ergebnisse sagen nicht aus, dass unterschiedliche Standorte unterschiedliche Produktionsmethoden erfordern.
Resumen. Después del trasplante, muchos árboles entran en un período de crecimiento reducido que puede limitar sus beneficios ambientales y estéticos durante varios años. Se han desarrollado una cantidad de métodos de producción en vivero en un intento de reducir la malformación de la raíz, que se asocia a menudo con el crecimiento reducido. El objetivo principal de este estudio fue investigar de qué manera cinco métodos de producción en vivero afectan a los sistemas de raíces y el crecimiento de brotes post-trasplante. Otros objetivos fueron el estudio del efecto de la estructura de la raíz (fibrosa y gruesa) sobre la respuesta de los árboles a diferentes métodos de producción y el efecto de las condiciones en el sitio de trasplante. Cerezos dulces (Prunus avium L.) y robles rojos (Quercus rubra L.), con una circunferencia del tronco de 16 a $18 \mathrm{~cm}$, se produjeron a raíz desnuda, con bola y bola en arpillera, a raíz podada y en contenedor, y luego trasplantados en dos sitios donde se estudiaron durante cinco temporadas. El análisis visual mostró que los métodos de producción tuvieron un efecto claro sobre las bolas de raíces en el trasplante. Sin embargo, las diferencias no estaban claramente relacionadas con el crecimiento de los brotes. Todos los robles rojos trasplantados, independientemente del método de producción, mostraron una reducción significativa en el crecimiento de brotes en comparación con el crecimiento pre-trasplante. Los cerezos dulces con bola y en arpillera, con poda de raíces, y crecidos en contenedor restauraron el crecimiento de los brotes pre-trasplante tres años después de la plantación en un lugar más favorable. Los resultados sugieren que el cerezo dulce de raíces fibrosas fue más sensible a los métodos de producción diseñados para reducir el estrés del trasplante, en comparación con el roble rojo de raíces gruesas, y que el sitio afectó el tiempo requerido para el crecimiento normal de los brotes para ser recuperado. Los resultados no indican que sitios diferentes requieran árboles producidos de manera especial. 